\title{
Behind-the-Meter Storage
}

\author{
Anthony Burrell - NREL
}

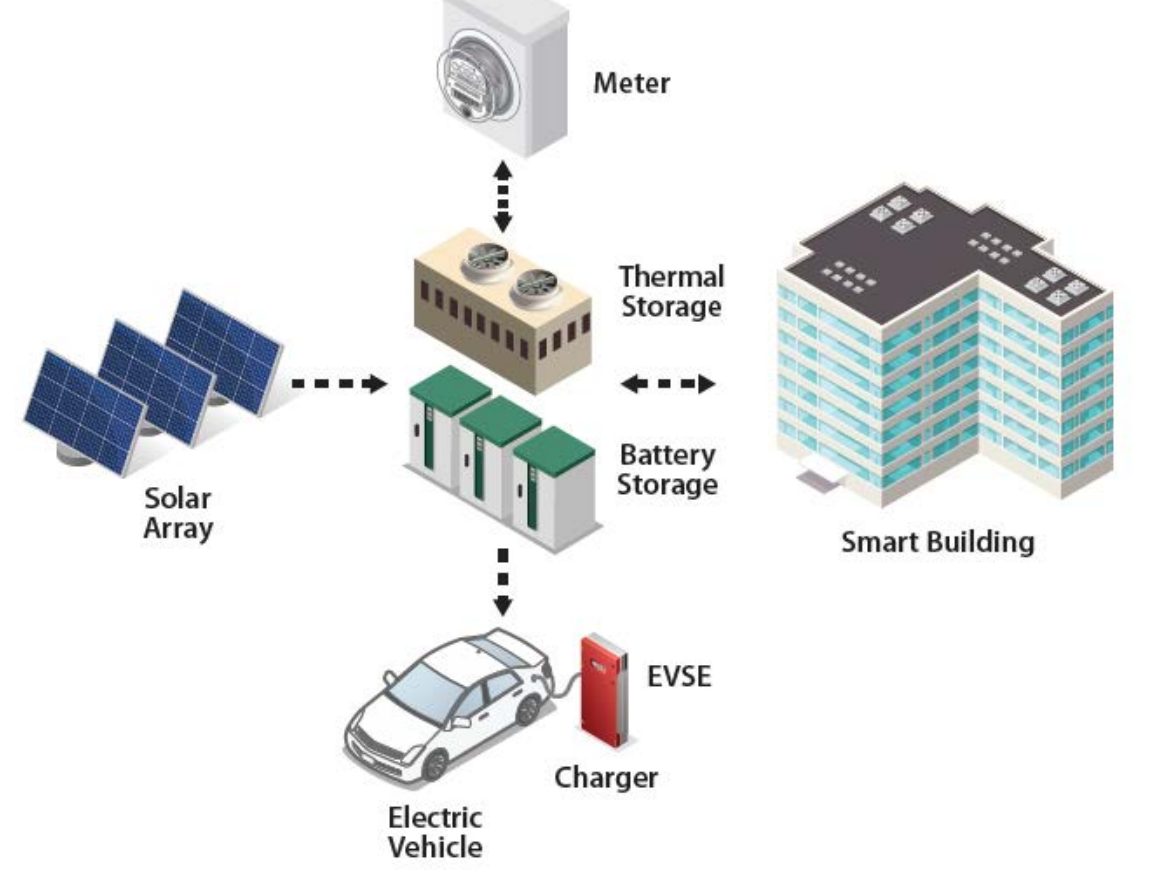

Partnership with the U.S. Department of Energy Vehicle Technology Office, Buildings Technology Office, Solar Energy Technology Office and The Office of Electricity

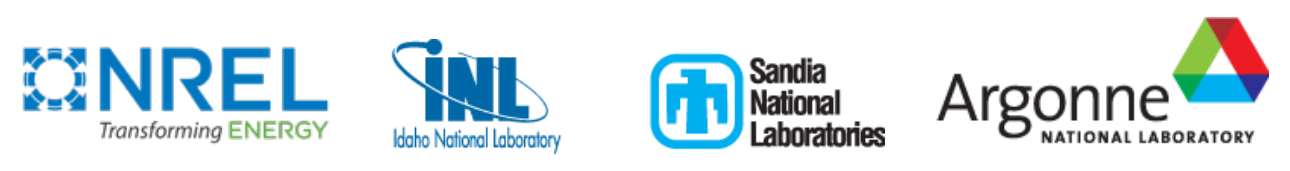




\section{CONTRIBUTORS AND ACKNOWLEDGMENT}

Support for this work from the Office of Vehicle Technologies, DOE-EERE, is gratefully acknowledged (Samuel

Gillard, Steven Boyd, and David Howell) the Office of Buildings Technologies, DOE-EERE (Erika Gupta, Sven Mumme, Monica Neukomm and David Nemtzow), and the Solar Energy Technologies Office, DOE-EERE (Andrew

Dawson and Dr. Becca Jones-Albertus) and The Office of Electricity - Energy Storage (Dr. Imre Gyuk)

\begin{tabular}{|l|l|l|l|l|}
\hline Ahmed Mohamed & Dheepak Krishnamurthy & Julieta Francis & Matthew Keyser & Ramchandra Kotecha \\
\hline Andrew Dawson & Don Karner & Kandler Smith & Matthew Shirk & Richard "Barney" Carlsol \\
\hline Andrew Meintz & Eric Bonnema & Kevin Gering & Michael Kintner-Meye Roderick Jackson \\
\hline Andy Jansen & Eric Dufek & Kyusung Park & Mohan Karulkar & Ross Kinz \\
\hline Anthony Burrell & Eric Wood & Loraine Torres-Castro & Monica Neukomm & Samuel gillard \\
\hline Brian Perdue & Erika Gupta & Madeline Gilleran & Monisha Shah & Sang Don Han \\
\hline Chad Hunter & Farrell, John & Margaret Mann & Monte Lunacek & Shawn Salisbury \\
\hline Christopher Neuman & Frank Fleming & Mary Werner & Nate Blair & Susan Babinec \\
\hline Daiwon Choi & Jack Deppe & Matt Mitchell & Nikitha Radhakrishnar Sven Mumme \\
\hline Darice Guittet & Jason Woods & Matthew Brandt & Paul Gasper & Yusheng Luo \\
\hline Vincent Sprenkle & Xiaolin Li & Yeyoung Ha & & \\
\hline
\end{tabular}




\section{Reducing $\mathrm{CO}_{2}$}

Total U.S. Greenhouse Gas Emissions

by Economic Sector in 2018

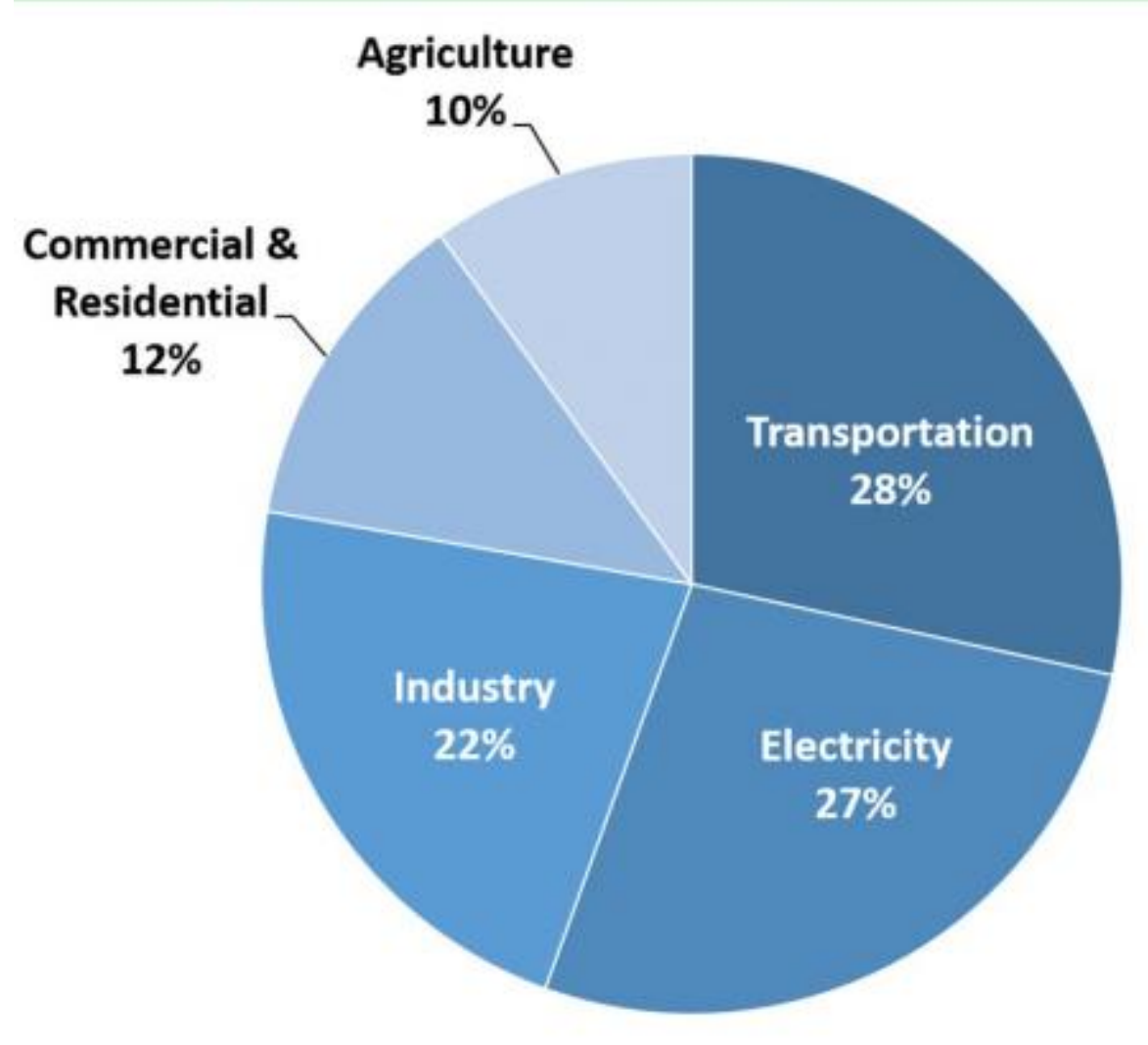

Transportation (28.2 percent of 2018 greenhouse gas emissions) - The transportation sector generates the largest share of greenhouse gas emissions.

https://www.epa.gov/ghgemissions/sources-greenhouse-gasemissions 


\section{No problem EVs are on there way}

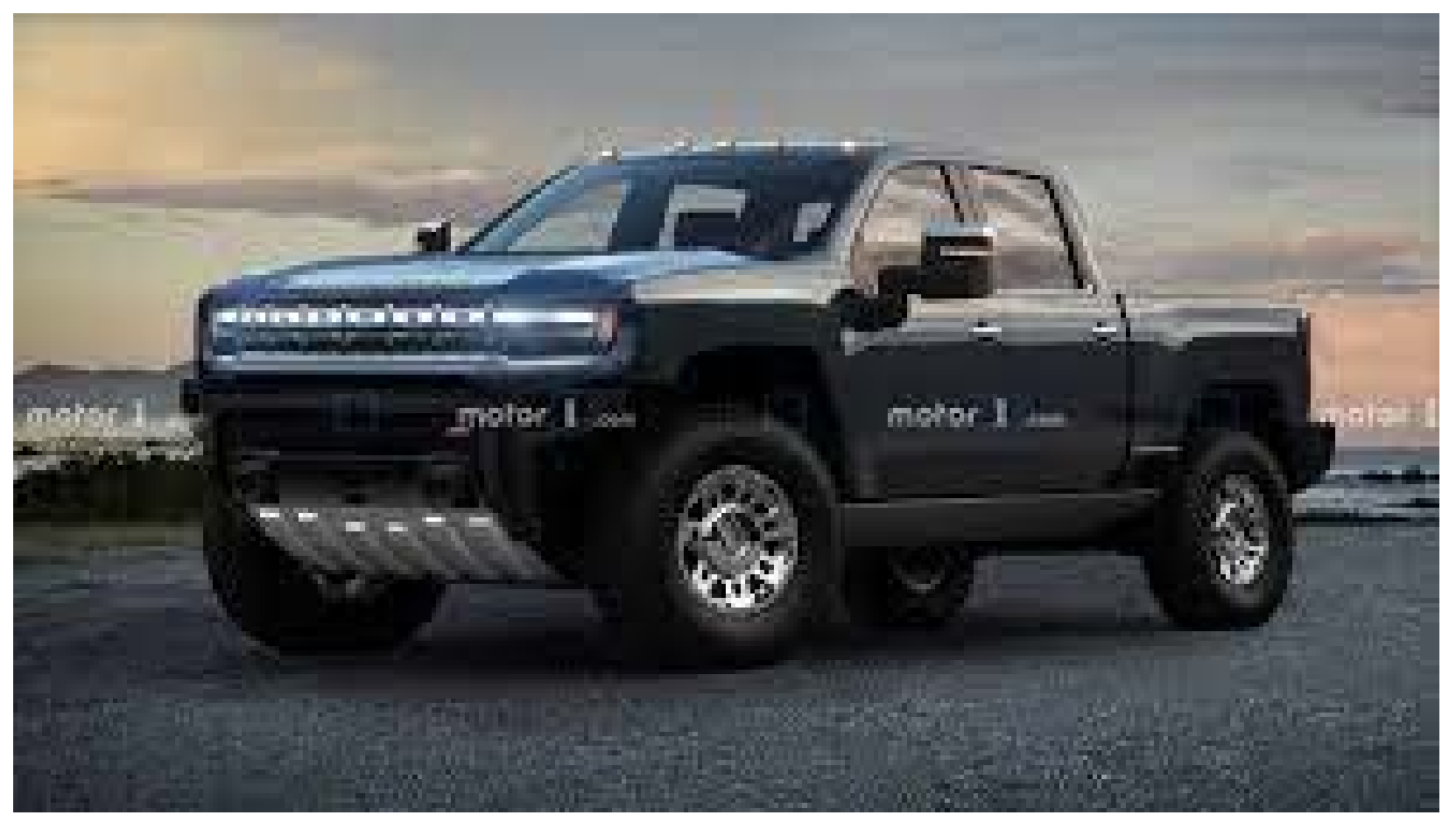

GM-ESTIMATED 350+MILE RANGE†

CHARGE NEARLY $100 \mathrm{MI}$. IN $10 \mathrm{MIN}$. $^{+}$

https://www.gmc.com/electric/hummer-ev 


\section{Consequences of EV deployment}
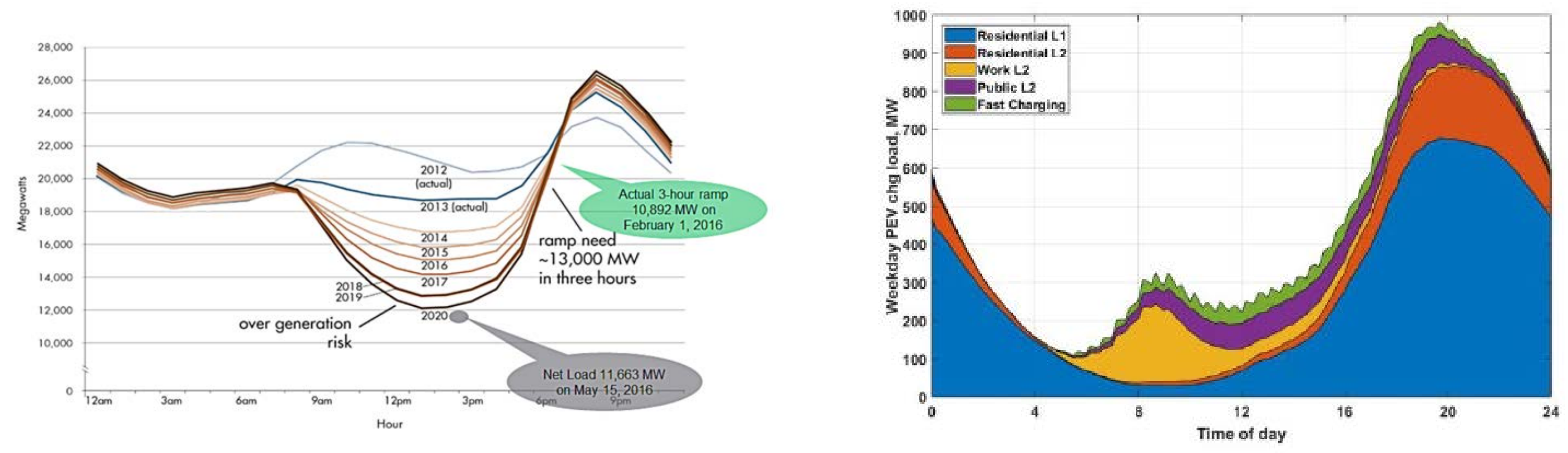

Source: California Energy Commission and NREL

What if California meets its EV targets - and we have not prepared 
Not everyone can charge at work or at home = no chance of owning an EV

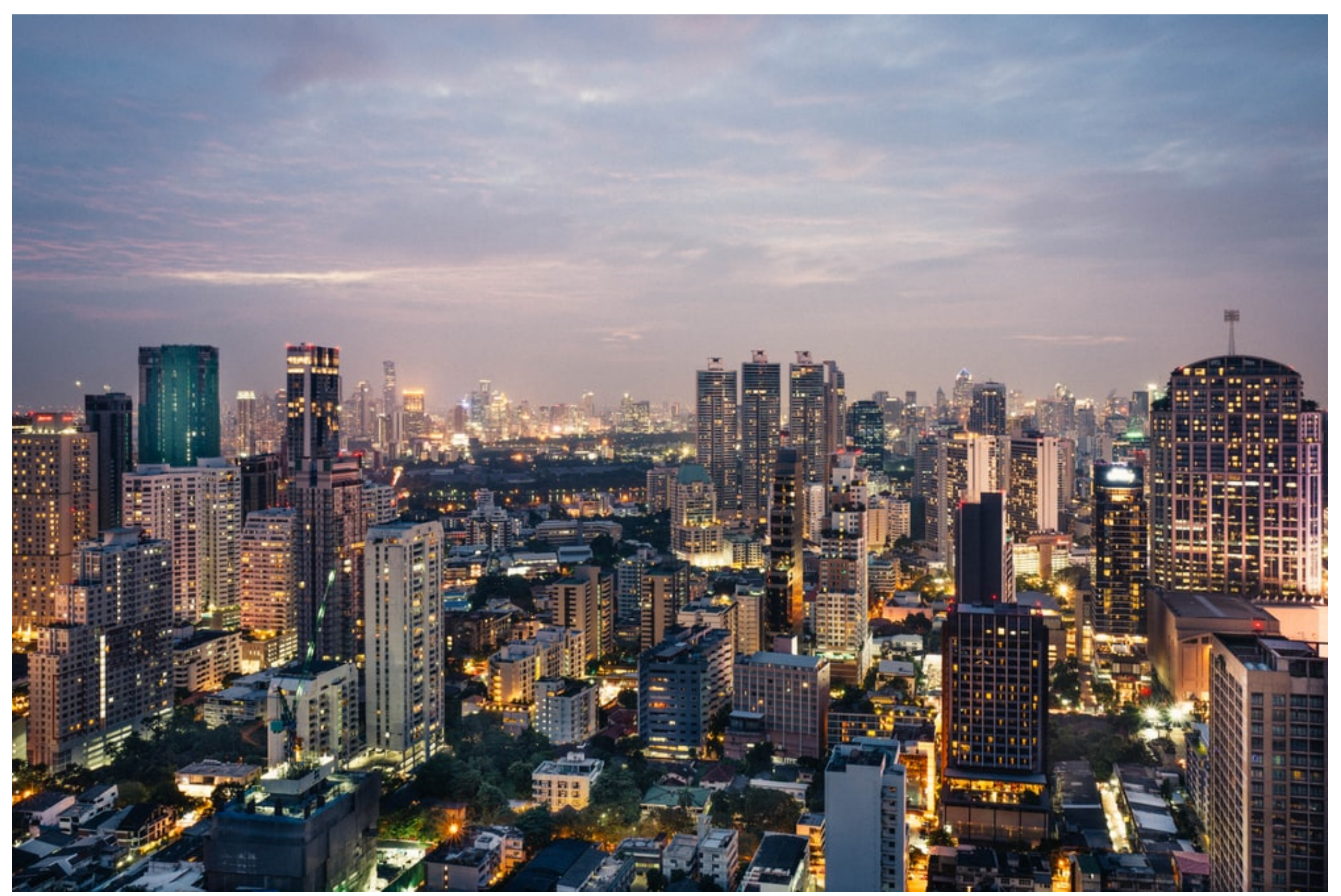




\section{One solution is the gas station equivalents.}

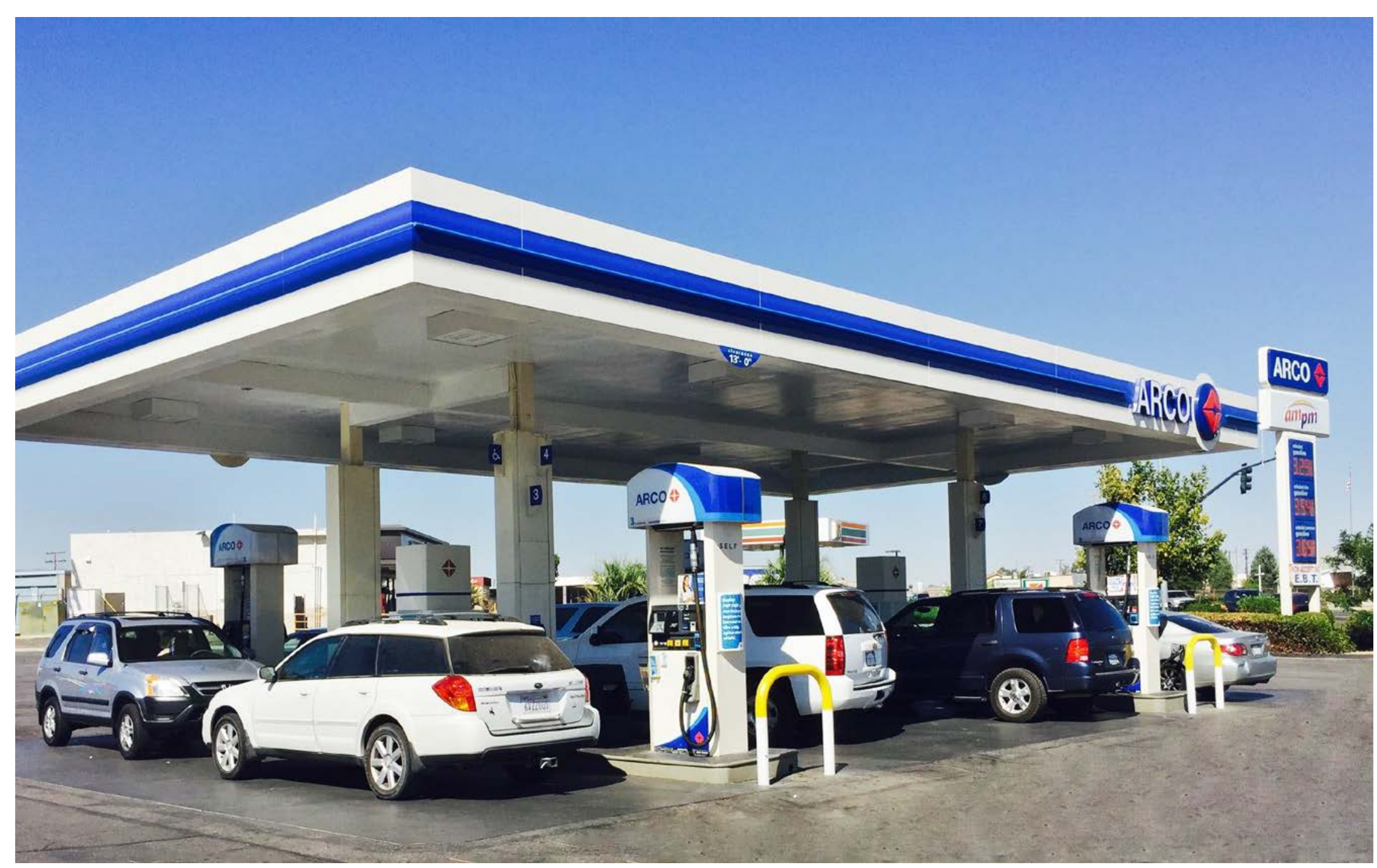

So worst case in this example could be Multi MW power requirements

Time for major supply upgrade could include years of planning and permitting.

Demand charges could make this very expensive 
Fast charging is a goal for all OEMs VTO target (aggressive) $\sim 200$ miles in 10 minutes

\section{Multi CCCV}

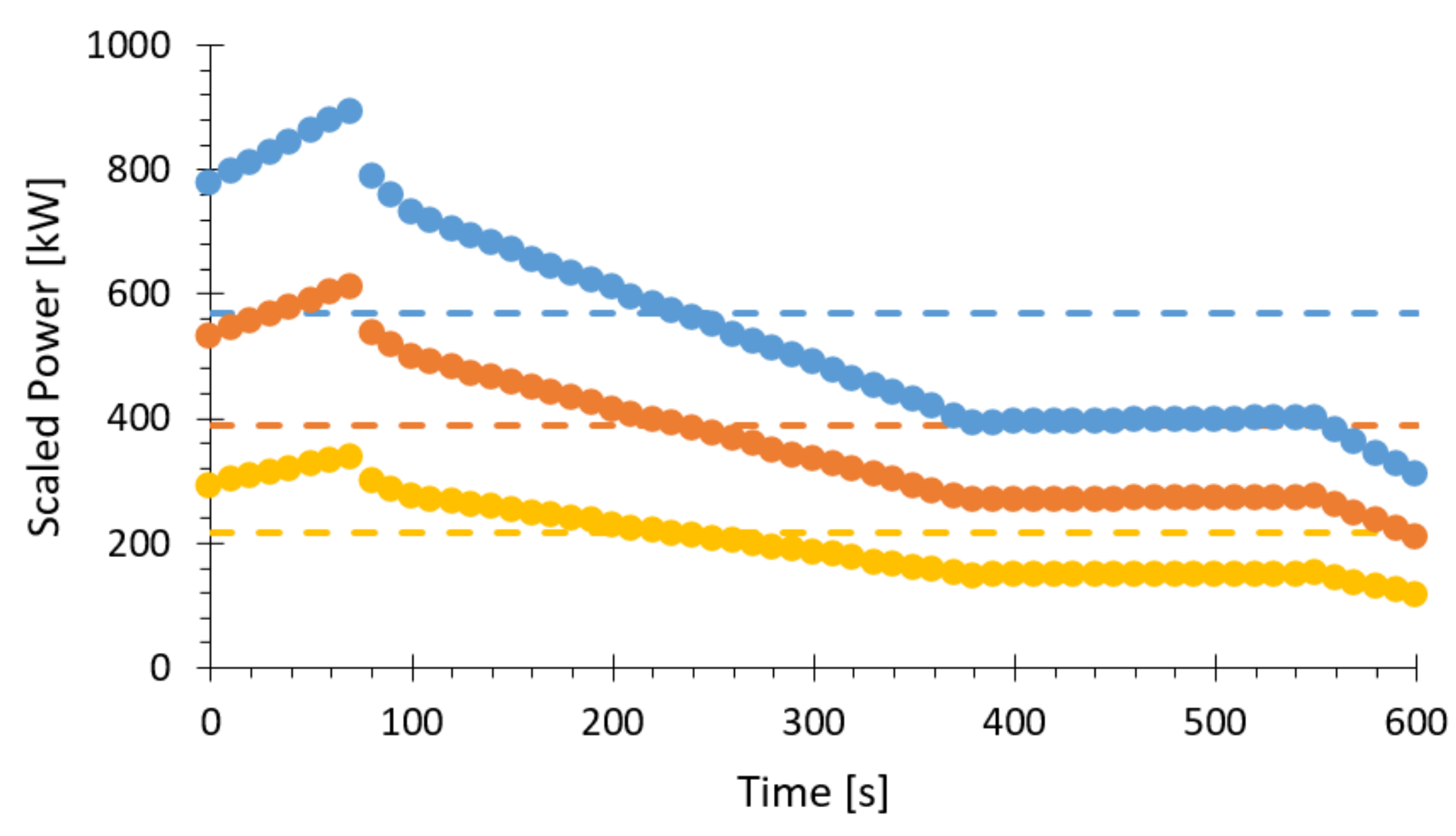

Example of XCEL

Changing profile.

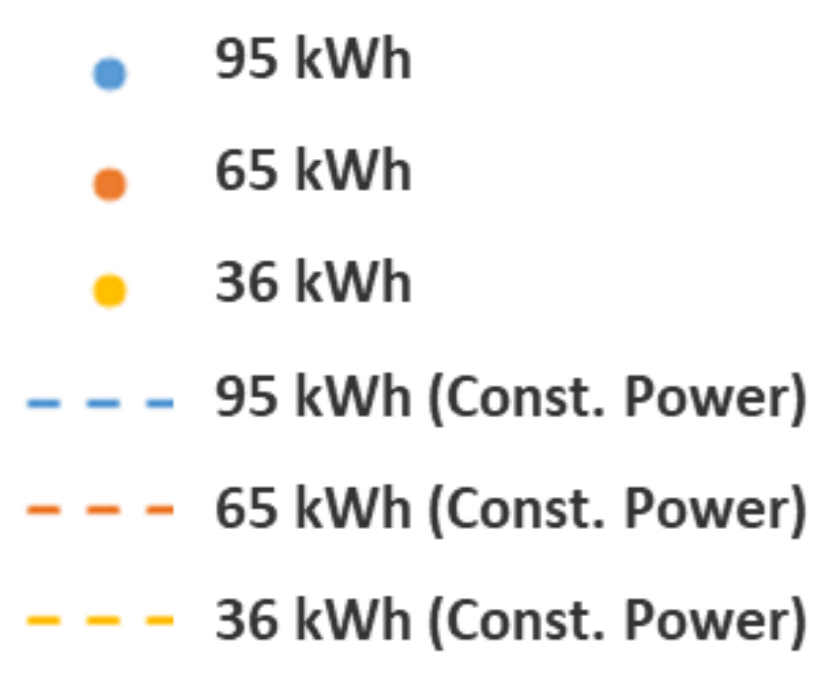




\section{Medium and Heavy Duty Vehicles make this worst}

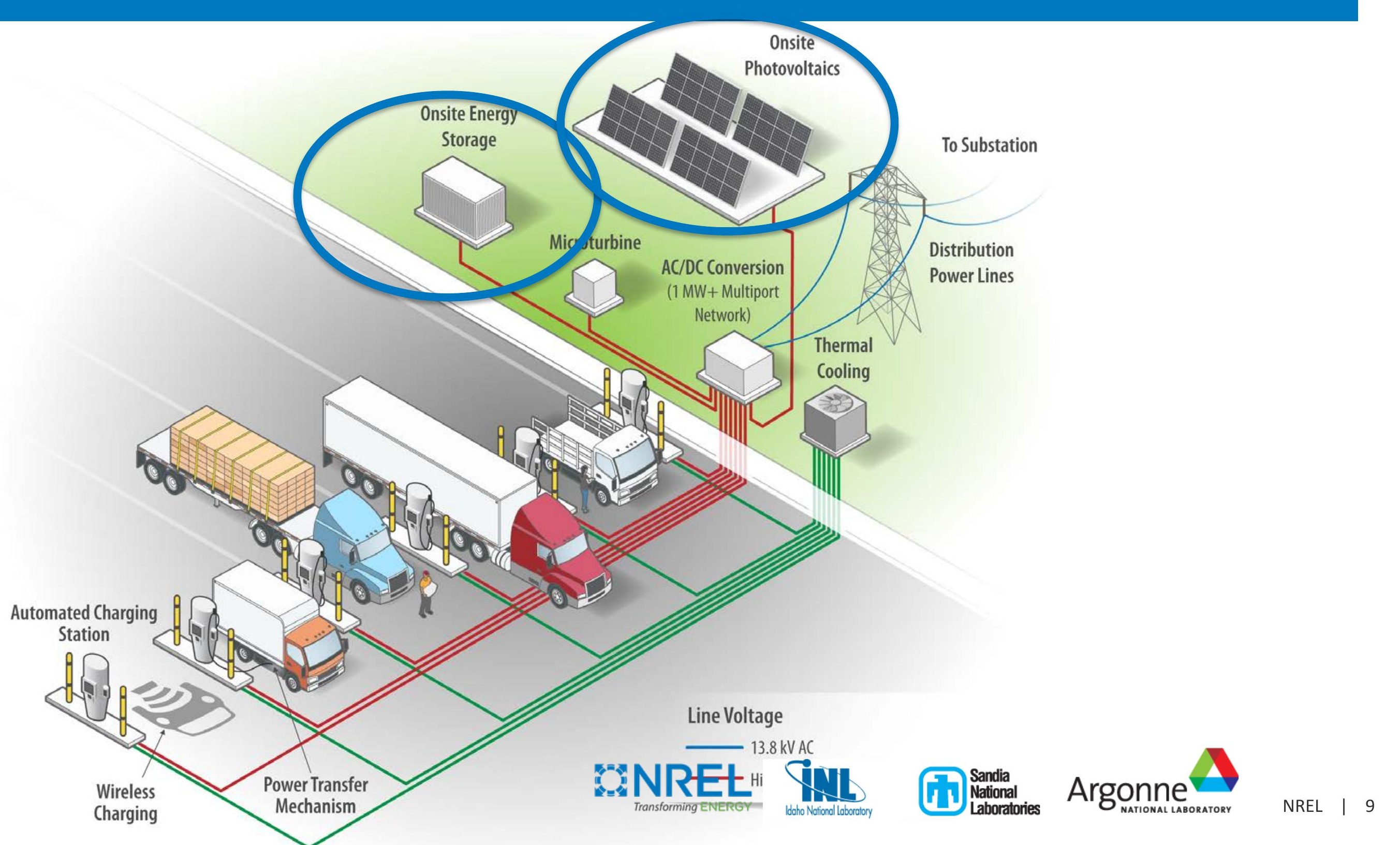


Behind-The-Meter Storage (BTMS)

\section{Low TRL Work Guided by System Level Thinking.}

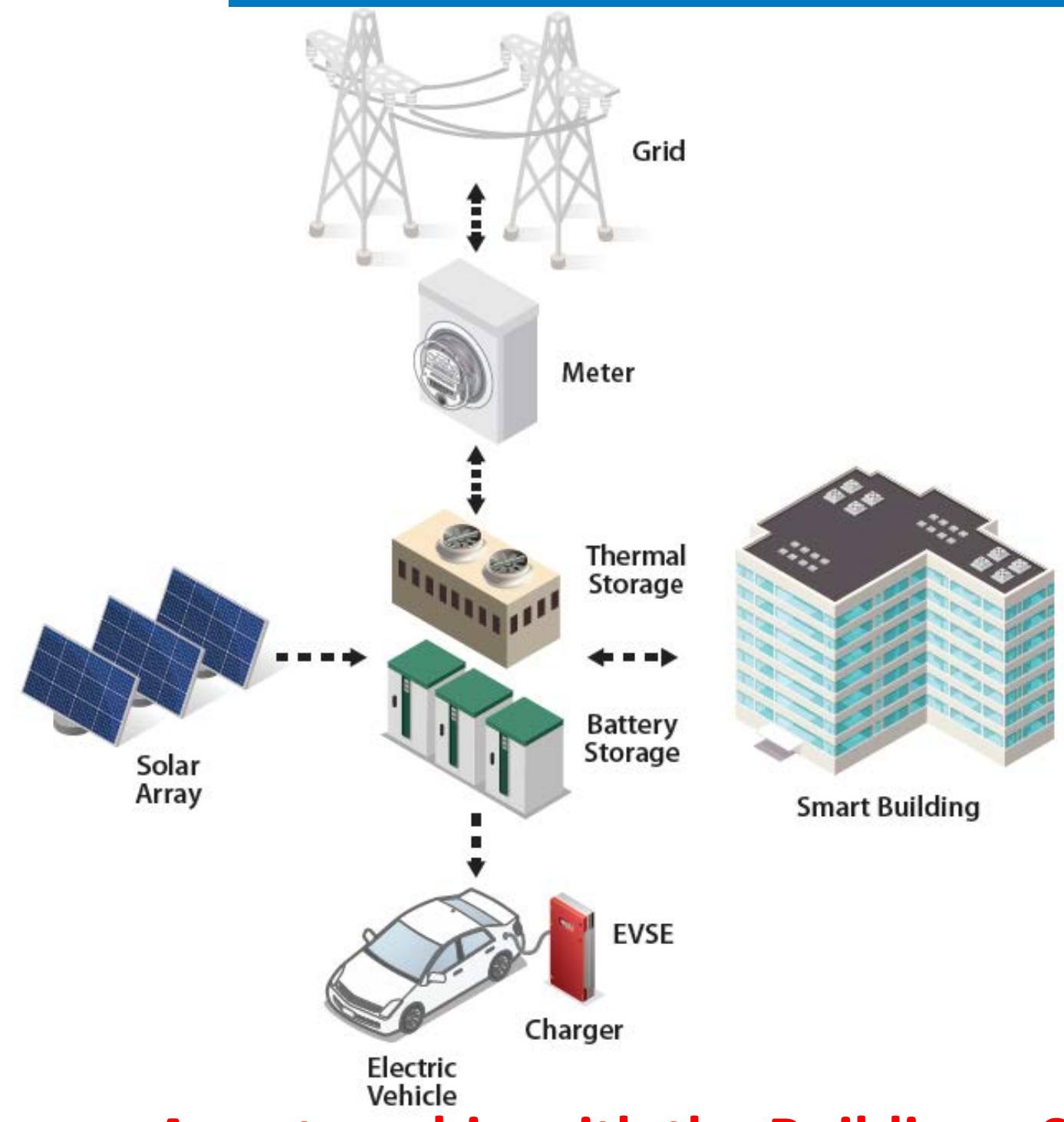

- Focus on specific end user outcomes

- Minimize cost of energy to user

- Buildings are the largest electrical users.

- EVs will be charged at buildings.

- Demand charges need to be eliminated.

- Grid impacts minimized.

- Integration of PV is/will be common.

- Both electrons and heat need to be stored.

- New batteries are needed

- New thermal storage are needed

A partnership with the Buildings, Solar, and Vehicles Offices 


\section{BTMS: Basic Premises}

- Technologically agnostic in the approach to storage systems (both electrochemical and thermal storage).

- EV Charging will occur at buildings.

- All low TRL research will be guided by the system requirements.

- Non-critical materials will be a foundation.

- Current targets for vehicles will not lead to batteries that meet long-term storage requirements.

- Thermal storage and management will enable optimizing energy efficiency and minimizing cost in buildings applications.

- System safety is critical in a building environment.
- Testing of new materials in full systems will be the metric for success (safety, lifetime, energy density, and cost).

- This project takes advantage of the major investment the VTO Battery program has made in infrastructure, capabilities, and materials development coupled with the BTO's investments in thermal management and storage.

- Ongoing and integrated cost analysis will be essential to success.

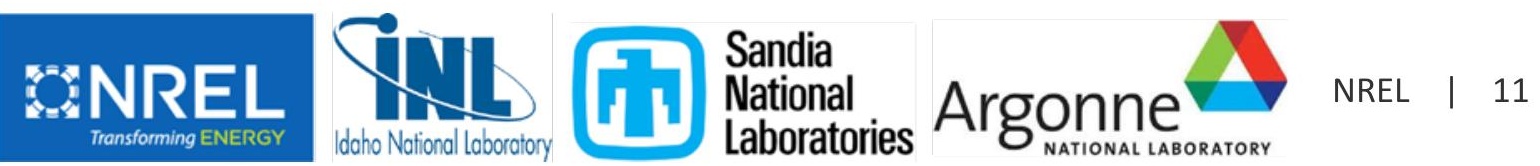


Analysis Process 


\section{Key Question}

What are the optimal system designs and energy flows for thermal and electrochemical behind-the-meter-storage with on-site PV generation enabling fast EV charging if we vary climate, building type, and utility rate structure?
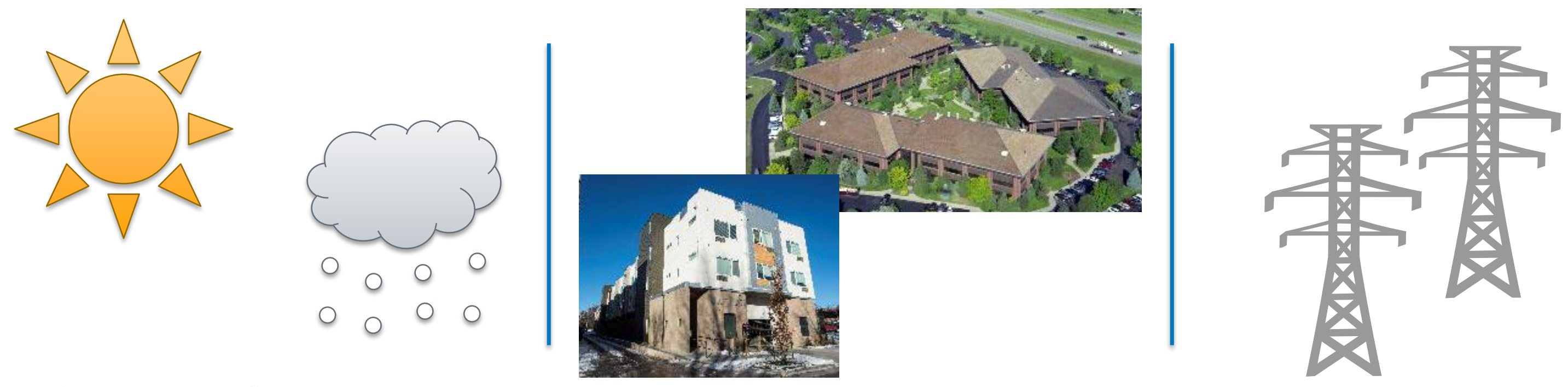
Optimize System Sizing to Minimize Cost: $P V+S B+E V+T E S$

- Solar photovoltaic (PV)

- Stationary battery (SB)

\section{Grid}

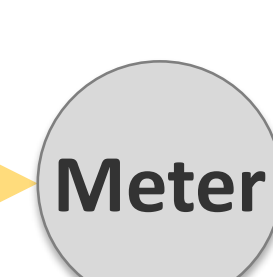

\section{PV}

Stationary

Battery

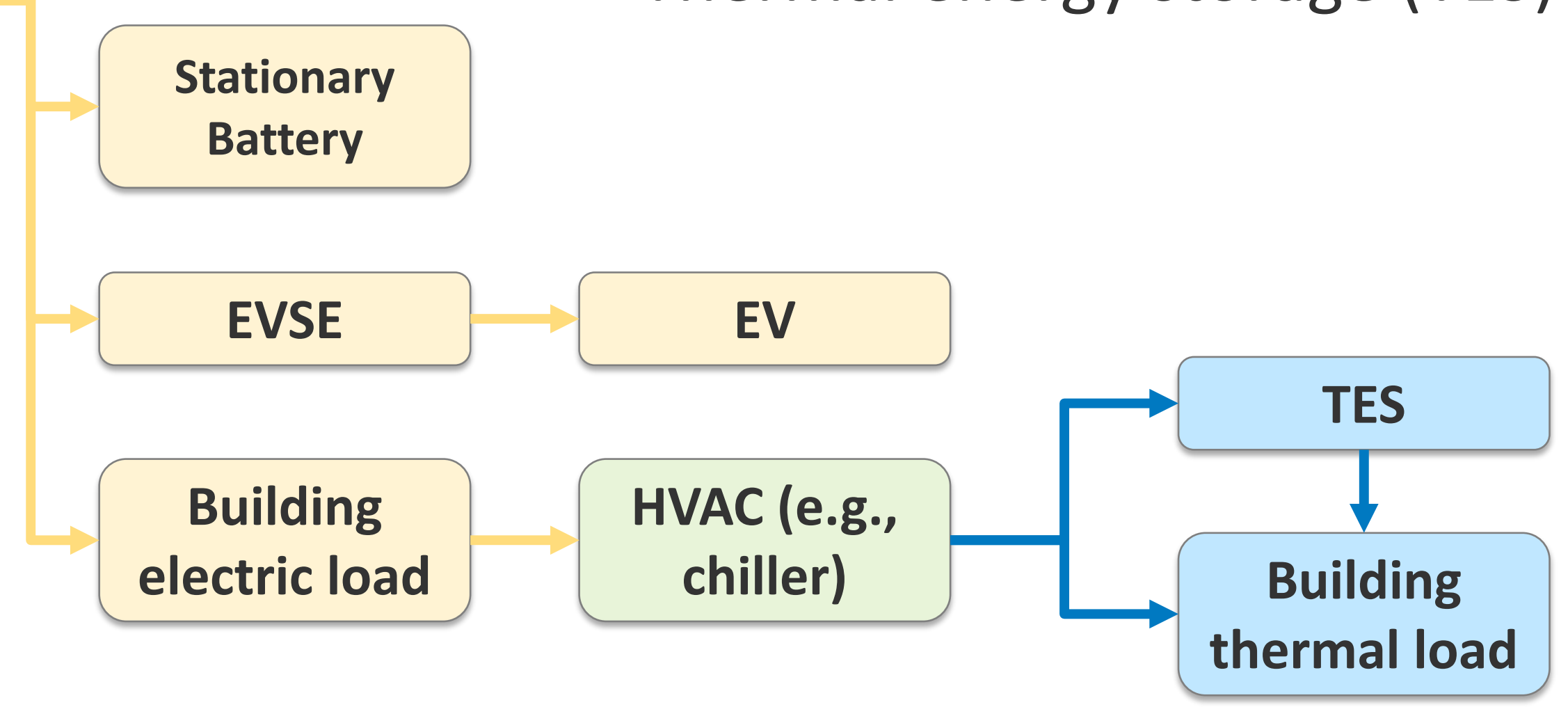

- Thermal energy storage (TES) 
Materials Choices 


\section{Electrical Energy Storage}

What do we need?

- Cost - upfront vs total cost

- Performance

- Lifetime

- Safety
Systems under evaluation

- Lithium ion various

- Lead Acid

- Nickel Zinc

- Nickel Metal Hydride

Volumetric limitations preclude current flow battery systems 


\section{Vehicle batteries may not lead to the best outcome}

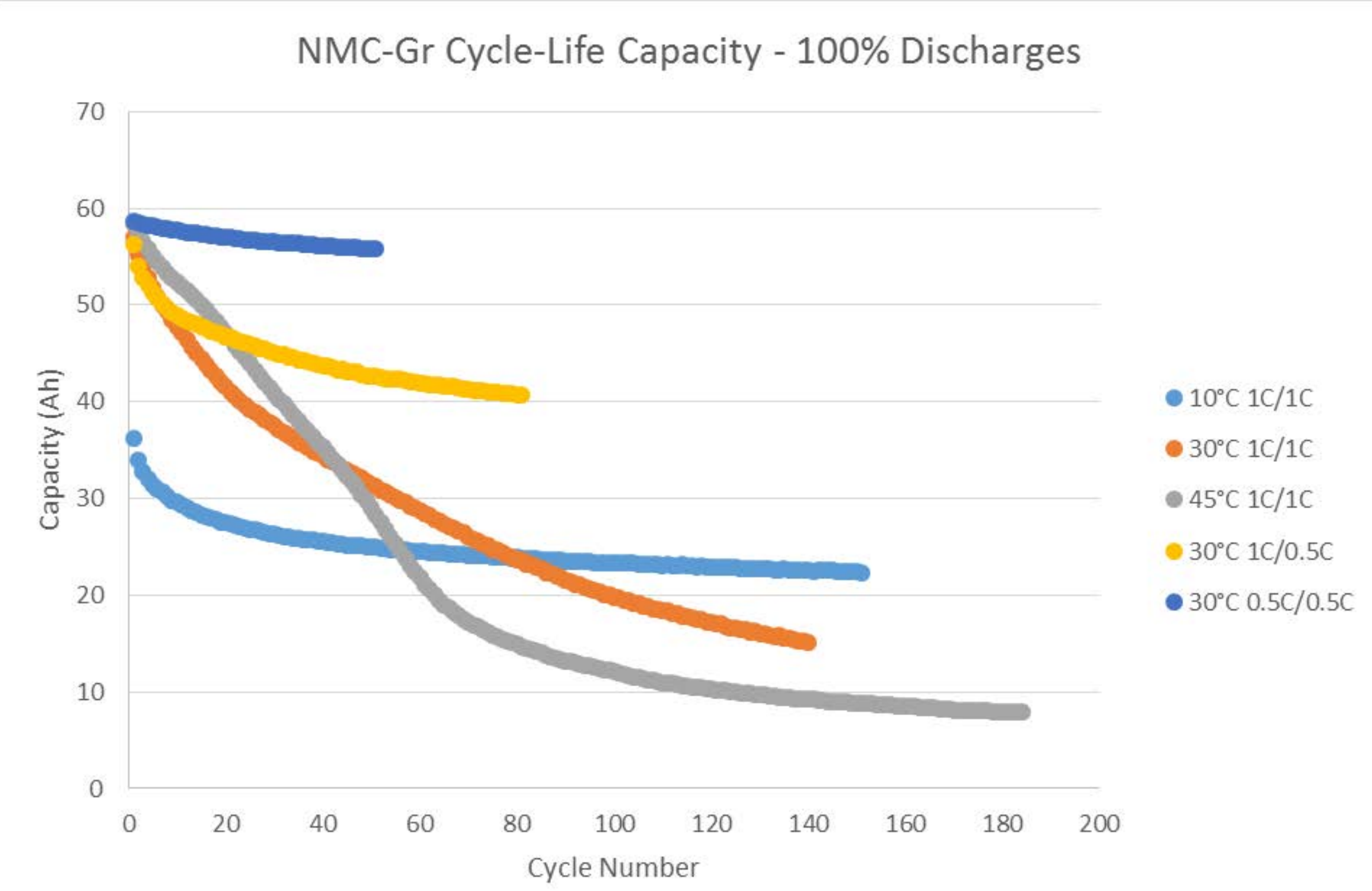




\section{Long life cell chemistries}

Capacity Retention of LFP/Graphite Cells Cycled at $30^{\circ} \mathrm{C}$

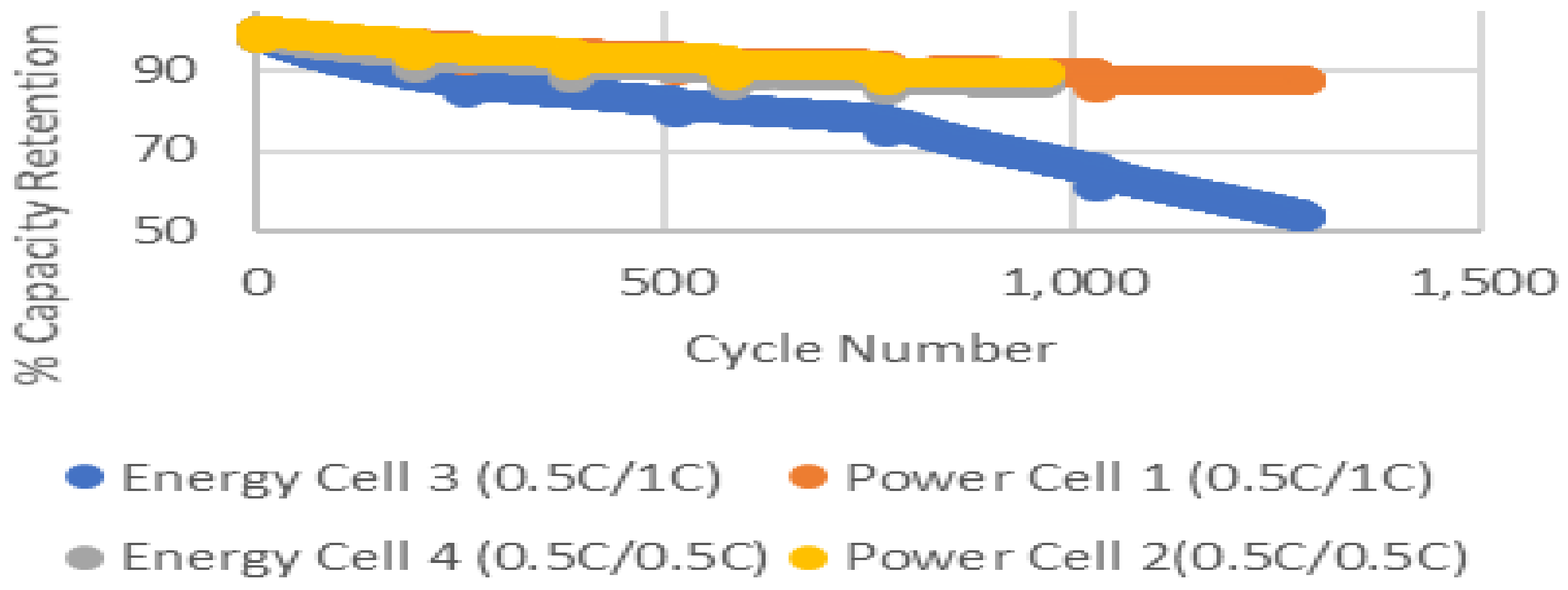




\section{LTO anodes}

Full Depth Cycling at $30 \mathrm{deg}$. C

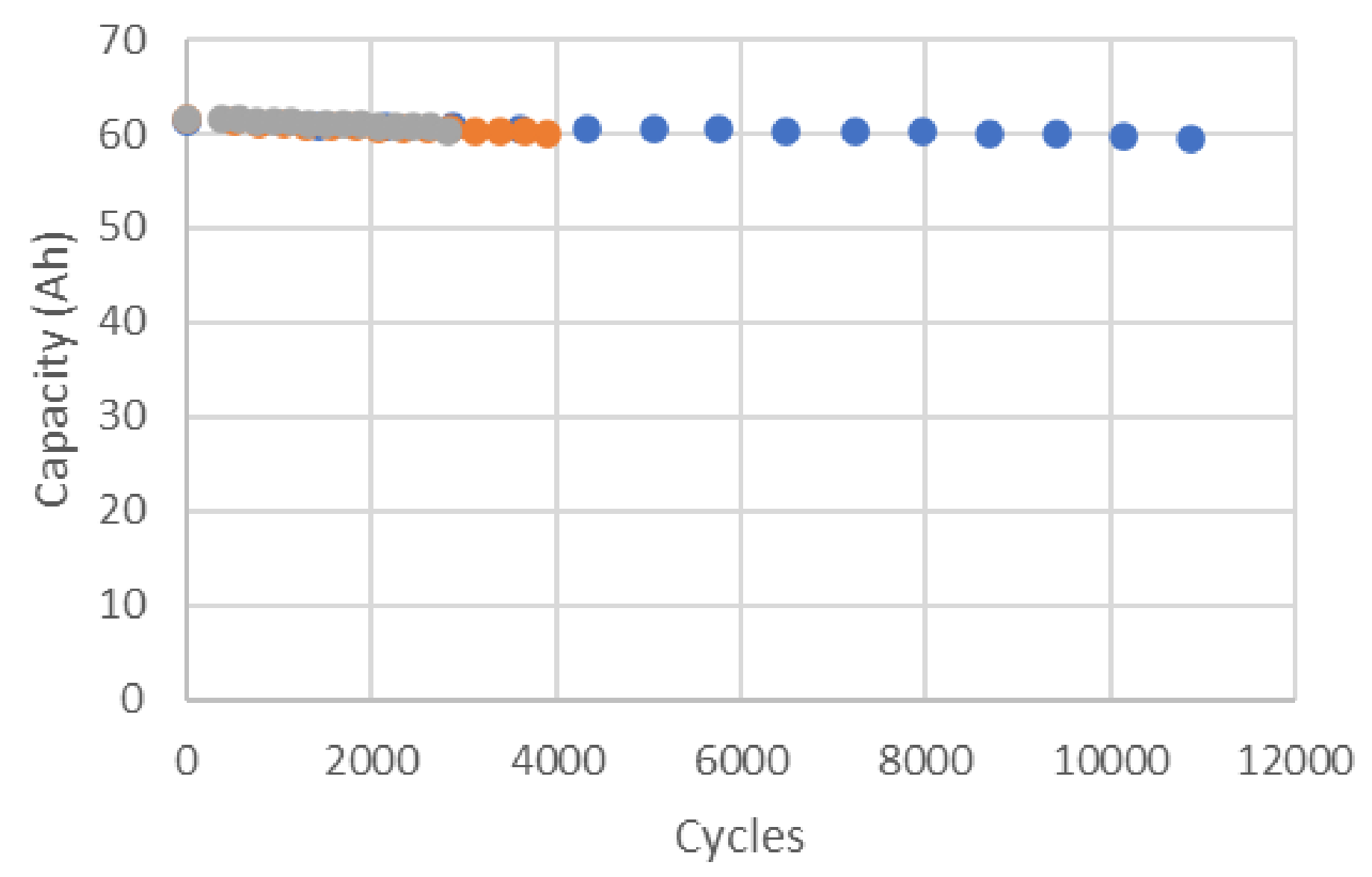

- $300 \mathrm{C} 1 \mathrm{C} / 6 \mathrm{C}$

- $300 \mathrm{C} 0.5 \mathrm{C} / 1 \mathrm{C}$

- $30 \mathrm{oC} 0.5 \mathrm{C} / 0.5 \mathrm{C}$ 


\section{LMO//LTO Chemistry}

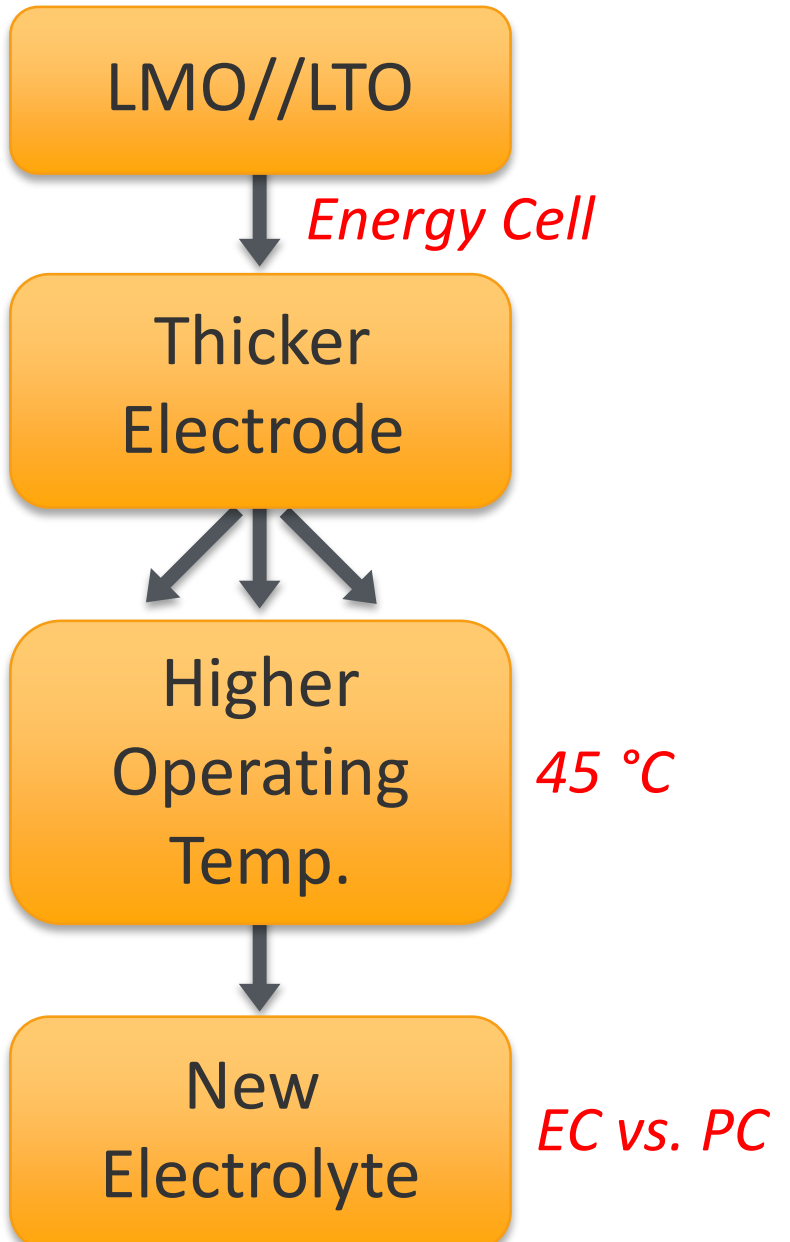

(a)

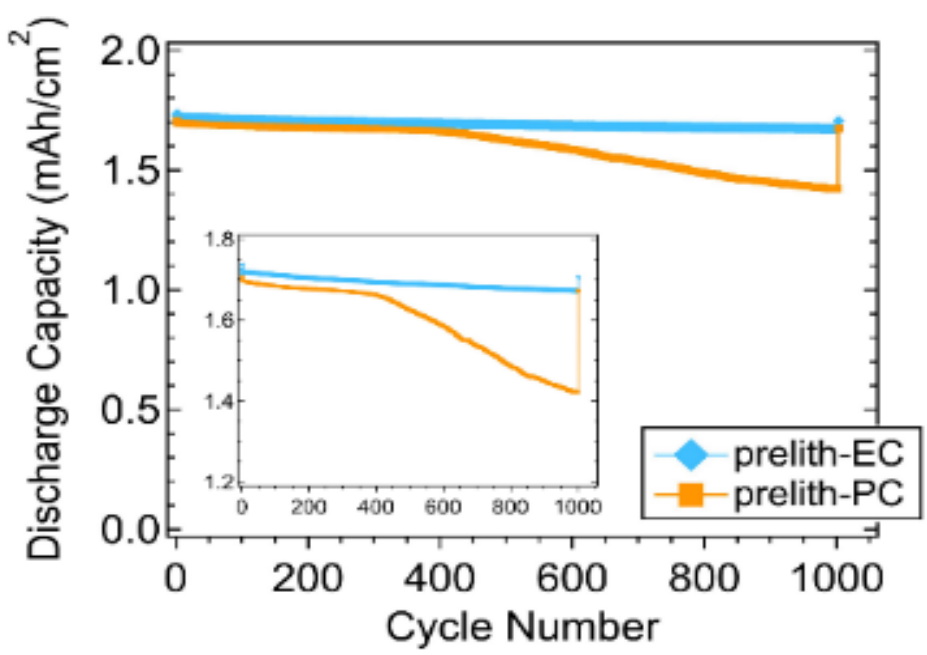

(c)

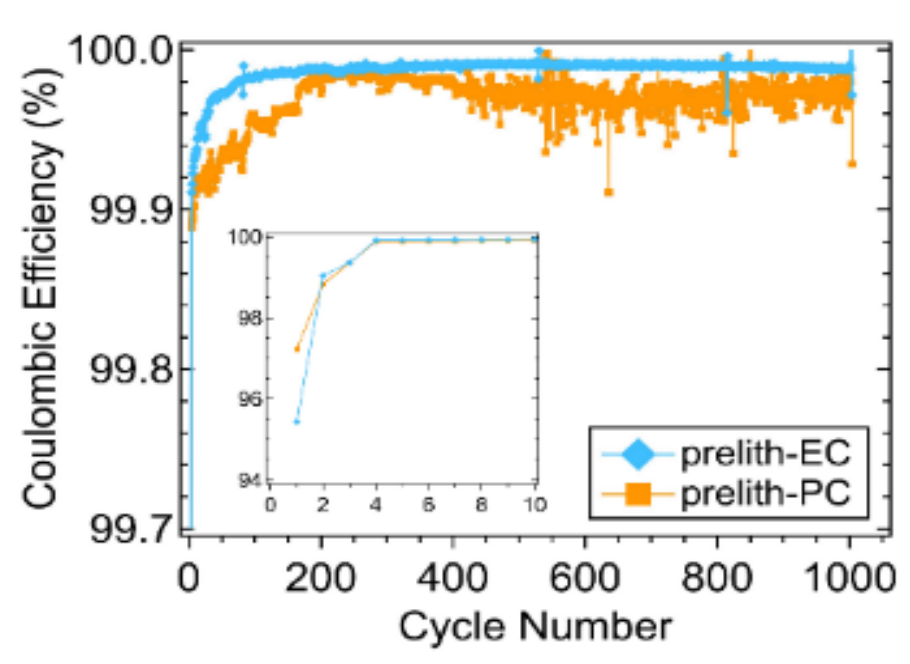

(b)

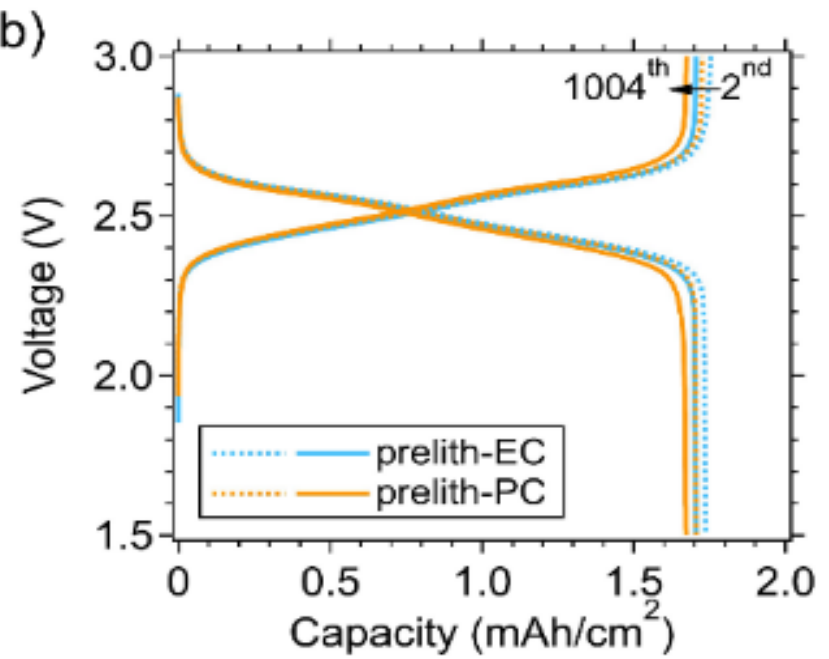

(d)

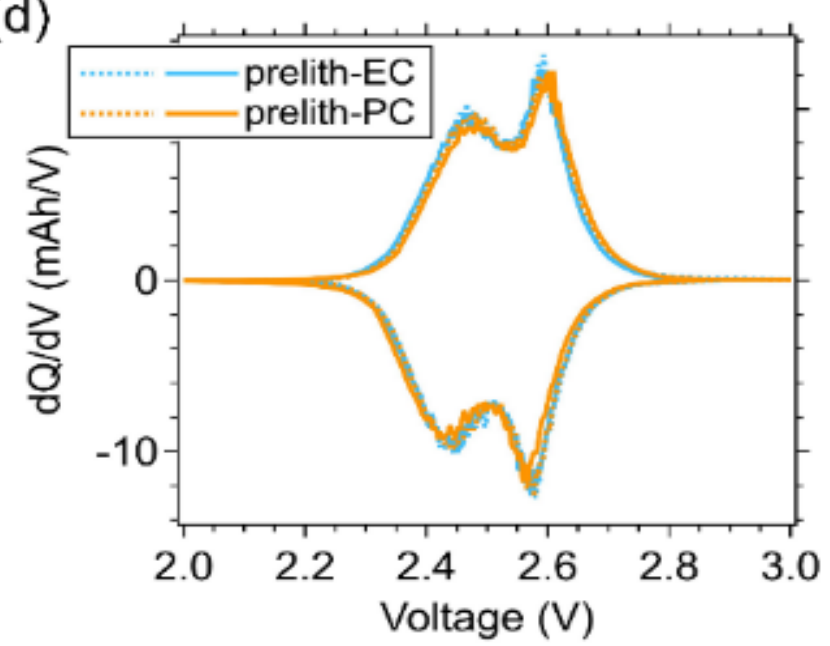




\section{$\mathrm{Ni}_{0.9} \mathrm{Mn}_{0.1}$ \\ (1.0 M LiPF 6 in EC)}

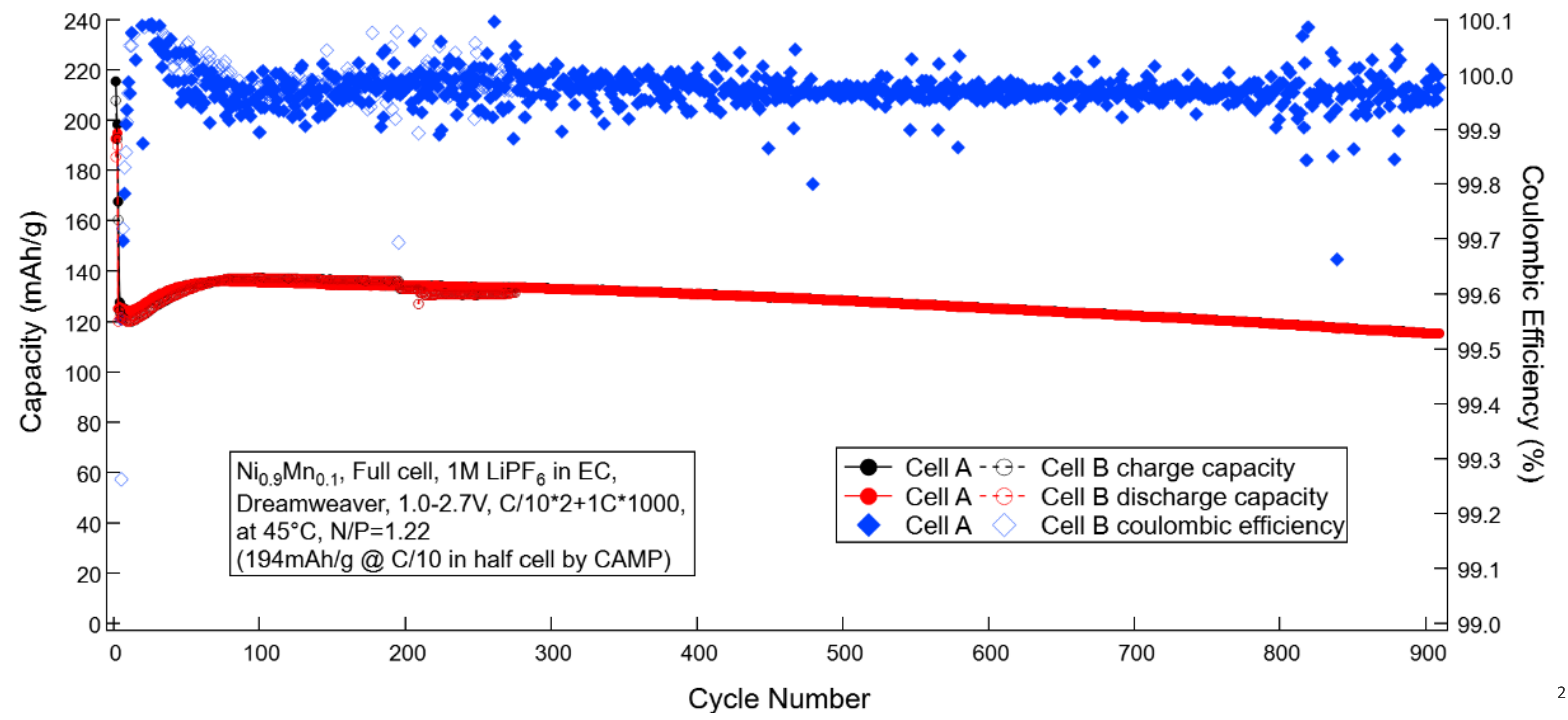




\section{$\mathrm{Ni}_{0.9} \mathrm{Mn}_{0.05} \mathrm{Co}_{0.05}$ (1.0 M LiPF in EC)}

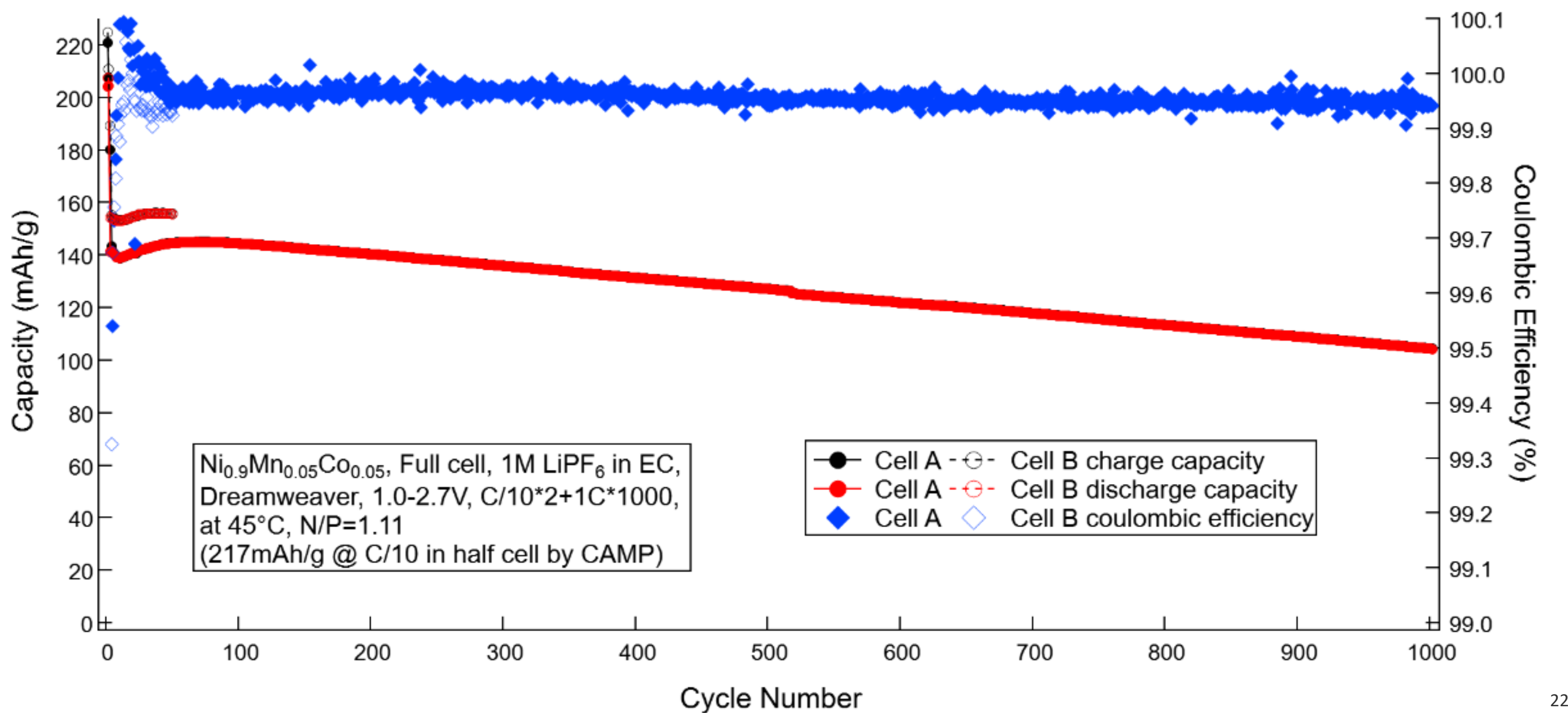




\section{LMR-NM Materials}
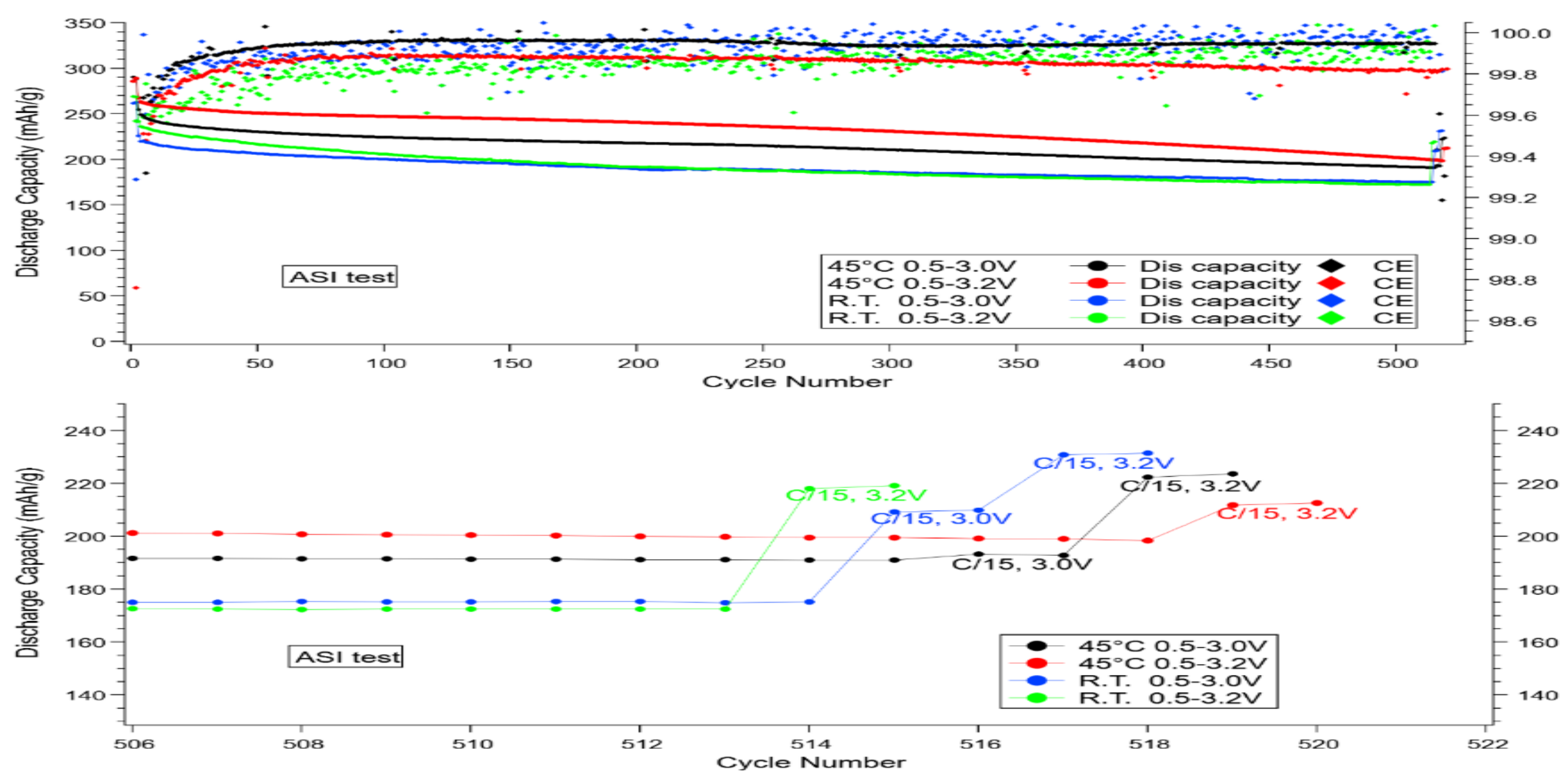
Cell Design 


\section{Effect of thickness on LTO utilization}

- Capacity utilization (delithiation) as a function of electrode thickness under various delithiation rates for LTO versus Li metal in coin cells (Gen2 electrolyte, $30^{\circ} \mathrm{C}, 1.0$ to $2.0 \mathrm{~V}$ ).

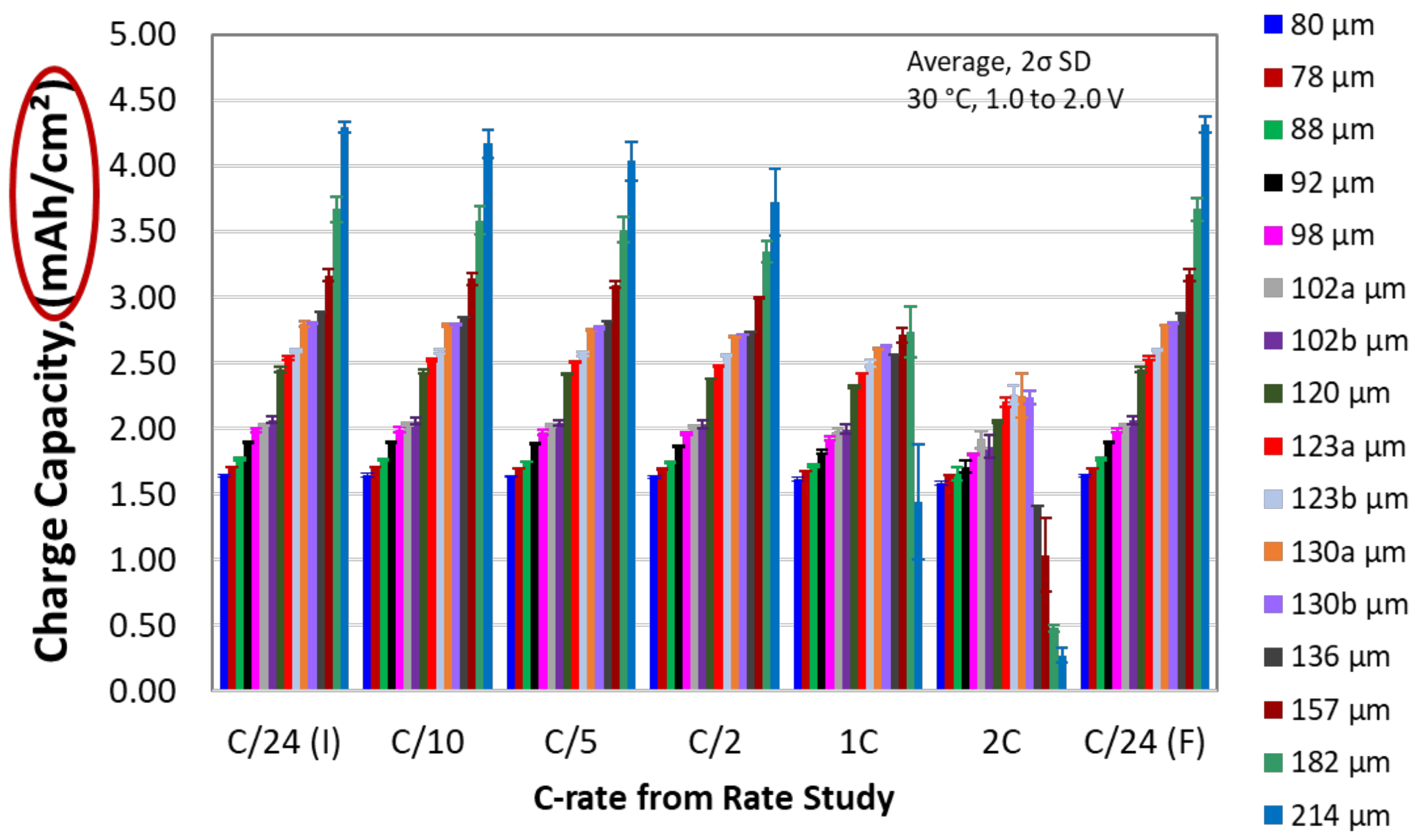


Cell Testing 


\section{Test Protocols for BTMS Cycle Life Target}

The BTMS Cycle Life Testing Protocol tests a battery designed to provide peak shaving for 24 10-minute fast charges at peak station power each day

- This yields 2 cycles/day

- The two illustrated scenarios show the extreme cases of vehicle arrival that can utilize maximum battery capacity over 24 hours

\begin{tabular}{|c|c|}
\hline $\begin{array}{c}\text { Cycle Life } \\
\text { Target }\end{array}$ & $\begin{array}{c}\text { Calendar Life } \\
\text { Target }\end{array}$ \\
\hline 10,000 Cycles & 20 Years \\
\hline
\end{tabular}

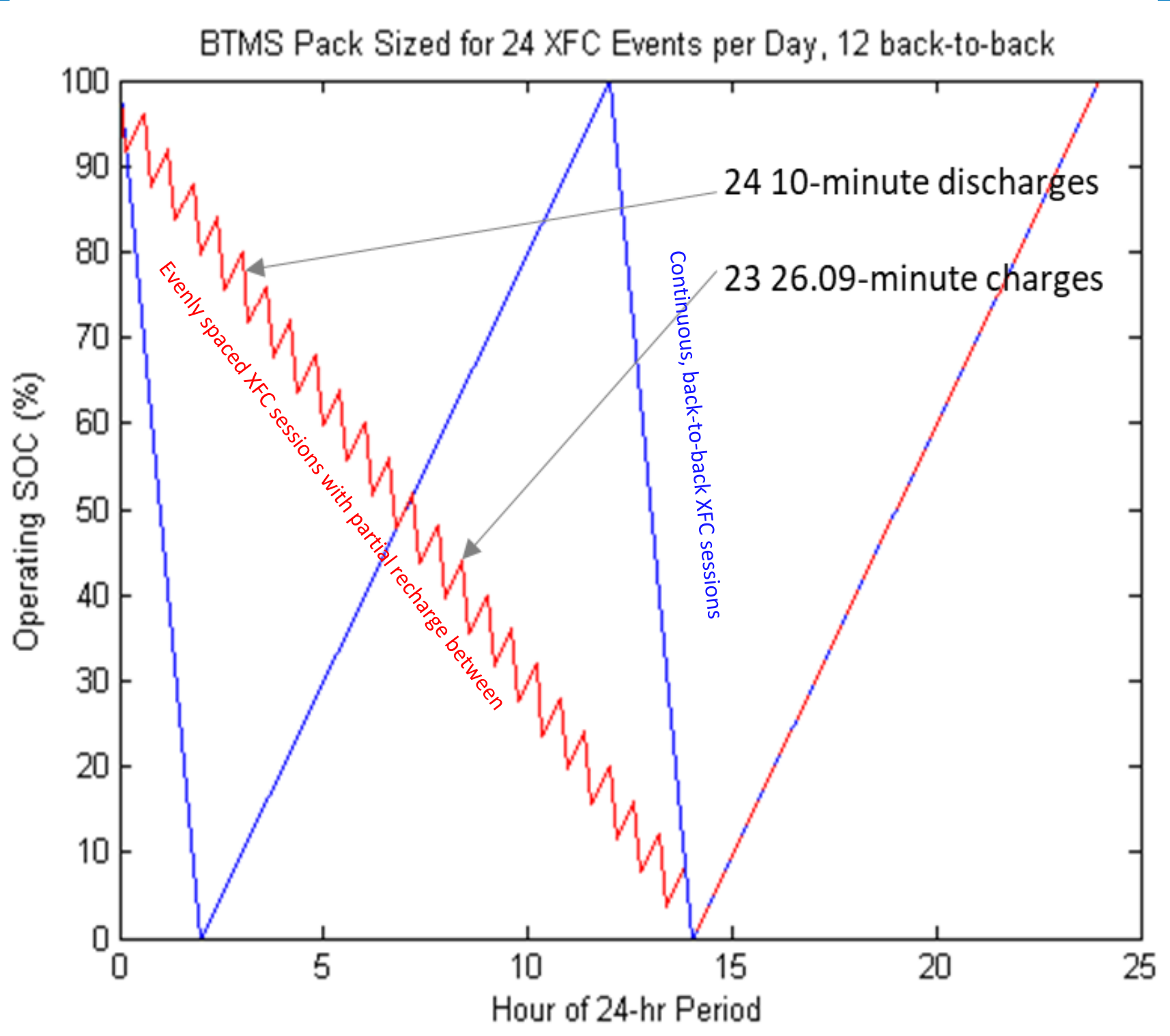


Rack Design 


\section{Enabling Technologies for Advanced Rack Design}

Need to address the hazards associated with lithium-ion batteries used in stationary applications for BTMS to become a reality.

- $\quad$ BTMS program is assuming that existing and future quality control measures at battery manufacturing facilities will not eliminate all single cell thermal runaway events.

We are developing a strategy to enable a fail-safe rack design over a three-year period. "Fail-safe" is defined as preventing cell to cell propagation in a best-case scenario and preventing rack to rack propagation in a worst-case scenario.

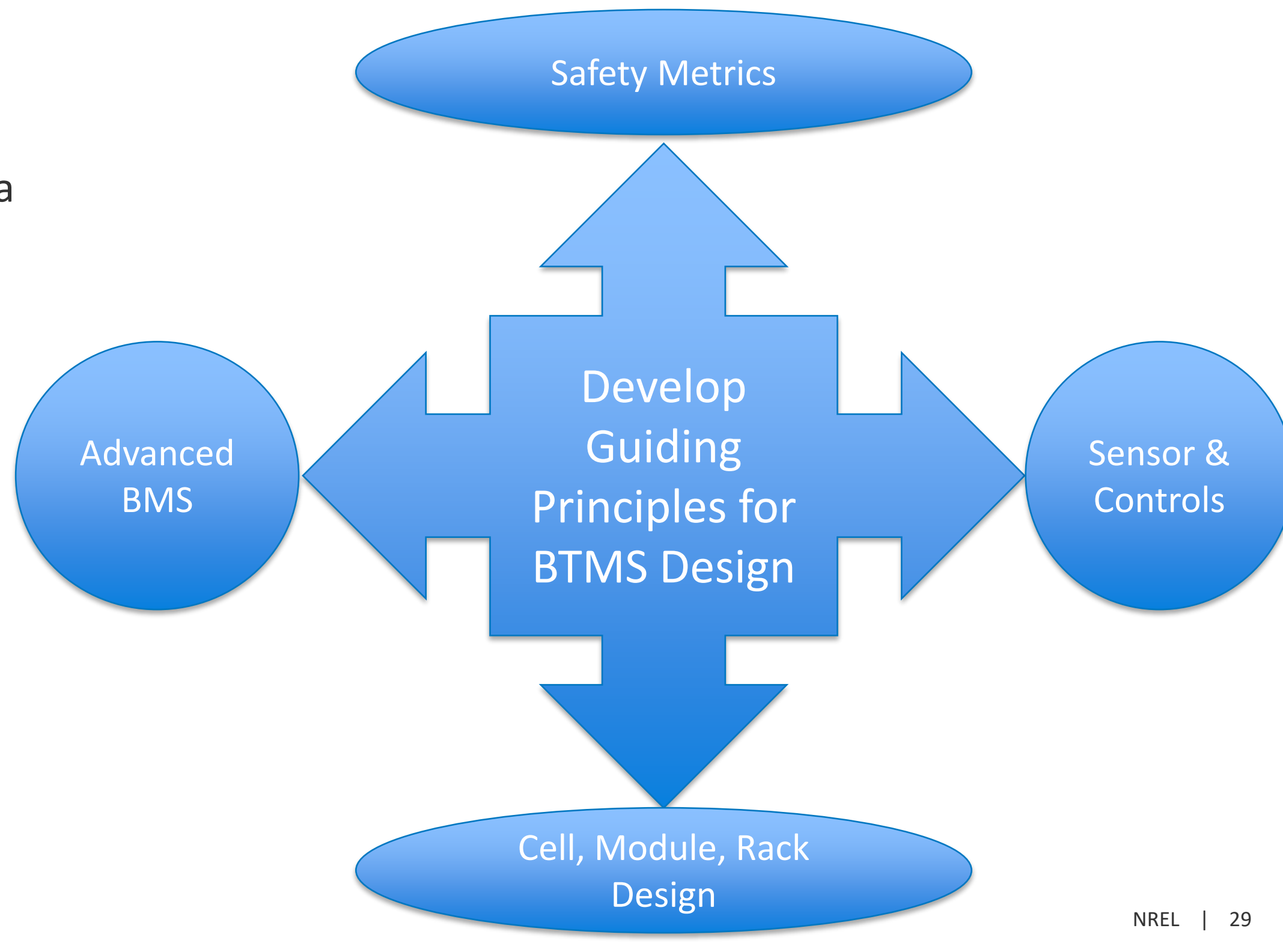


Thermal Storage 


\section{Thermal Storage Materials Research}

nature

\section{ARTICLES}

https://doi.org/10.1038/s41560-021-00778-w

Check for updates

\section{Rate capability and Ragone plots for phase change} thermal energy storage

Jason Woods $₫ \square$, Allison Mahvi $\odot$, Anurag Goyal $\odot$, Eric Kozubal $\odot$, Adewale Odukomaiya $\odot$ and Roderick Jackson

a

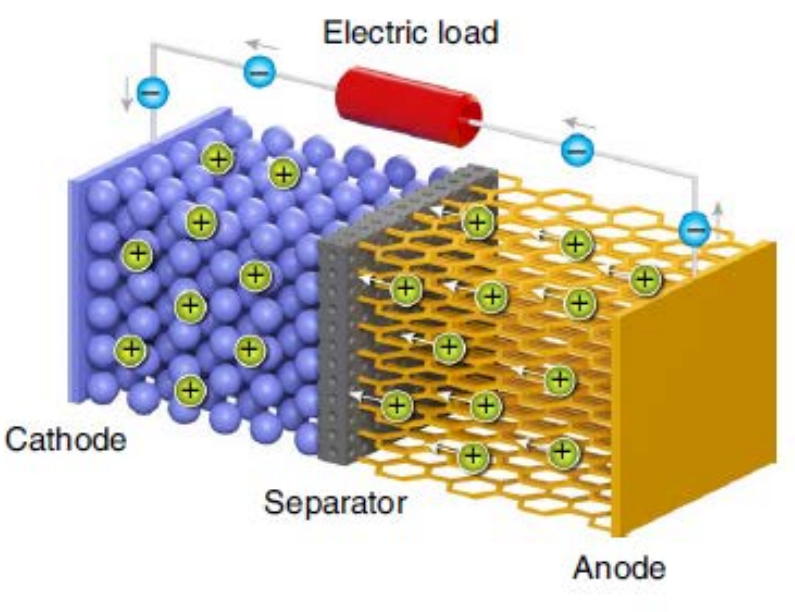

b High-temperature

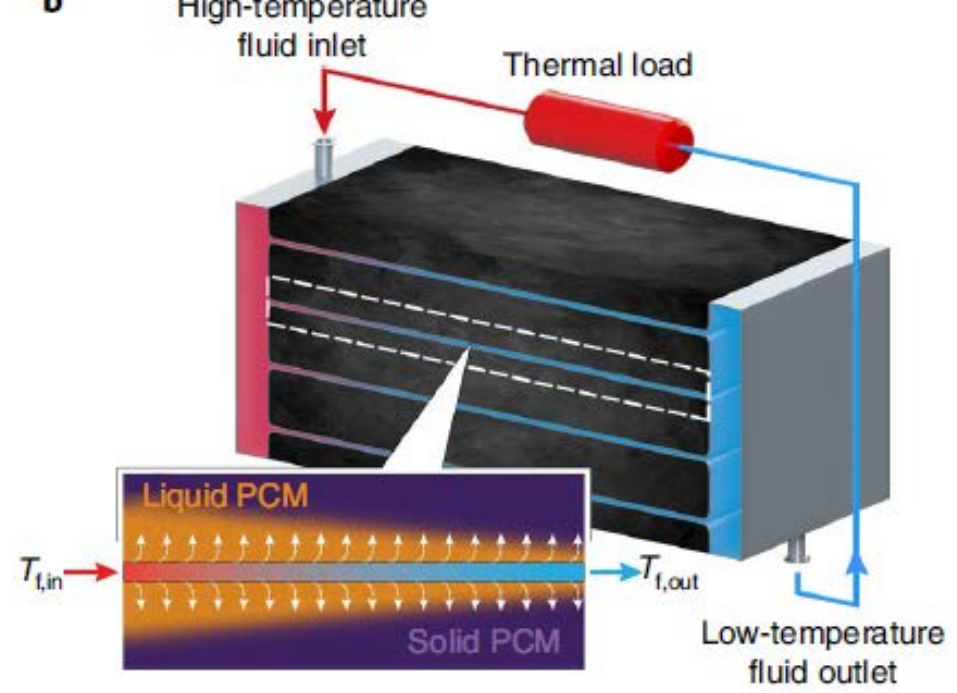

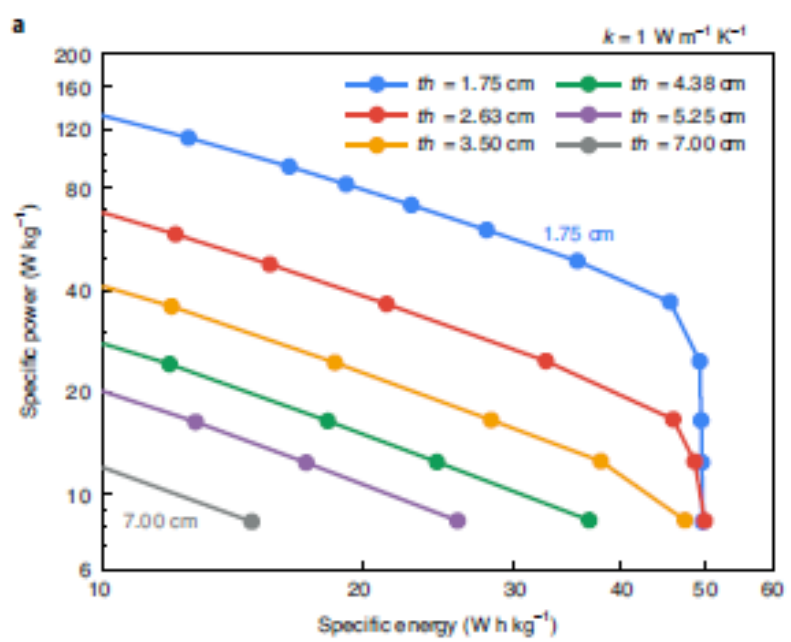

b

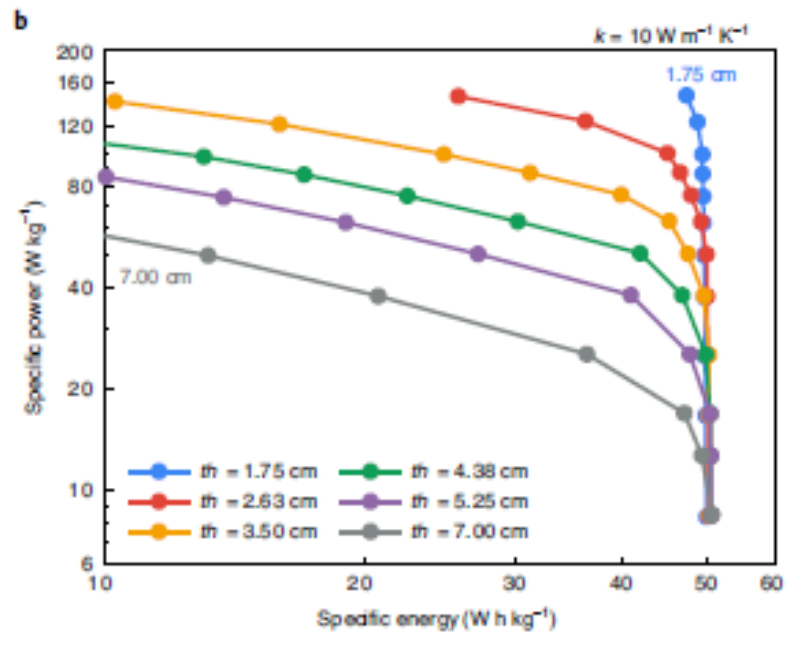

Fig. 5 | Effect of PCM thickness on Ragone curves for two thermal conductivities. Specinic power and energy are shown for thicknesses (th) between 1.75 and $7 \mathrm{~cm}$. $\mathbf{a}, 1 \mathrm{Wm}^{-1} \mathrm{~K}^{-1} \cdot \mathbf{b}, 10 \mathrm{Wm}^{-1} \mathrm{~K}^{-1}$. All other thermophyslal propertles, Including the latent heat, are kept the same. The ilnes are shown as guldes for the eye between the evaluated $C$-rates To access the fuil capacity of the system, the thickness of the PCM is IImitted at high power rates and low thermal conductivitles. 
VTO-BTO Laboratory 


\section{Unique ARIES Resources}

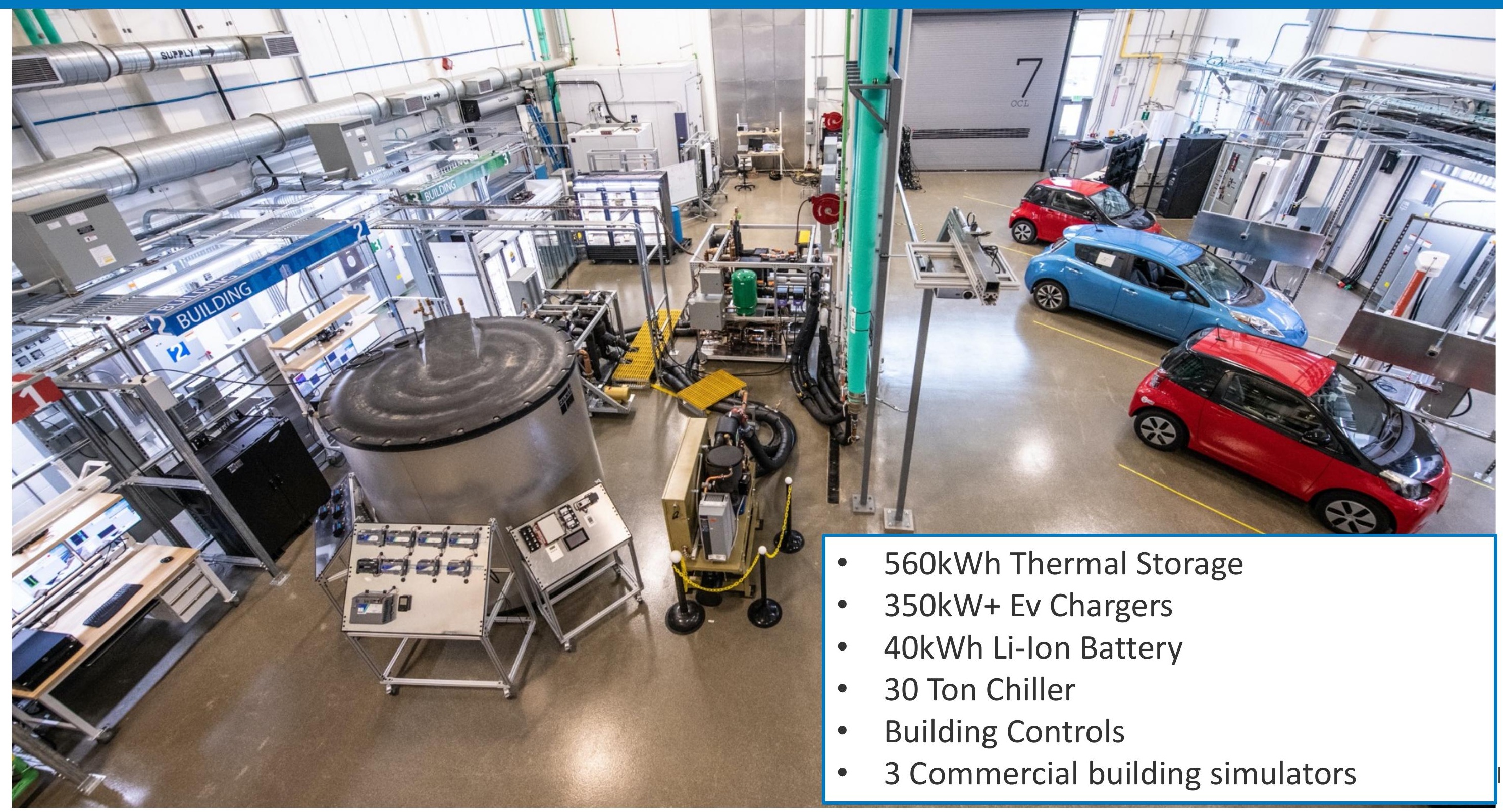

